\title{
Pengaruh Vaksinasi BCG Terhadap Serum Interferon Gamma pada Kasus Asma Ekstrinsik Atopi Anak
}

\author{
Yolanda Olivia Palandeng, * Diana Devi Takumansang - Sondakh \\ Bagian Ilmu Kesehatan Anak, Fakultas Kedokteran Universitas Sam Ratulangi, RSU Prof. Dr. R.D \\ Kandou Manado
}

\begin{abstract}
Latar belakang. Prevalensi asma makin meningkat, diduga berkaitan dengan kejadian infeksi pada anak yang menurun sehingga menyebabkan pergeseran keseimbangan antara limfosit T helper 1 (Th1) dan T helper 2 (Th2) ke arah predominan Th2. Infeksi mikobakterium dan vaksinasi BCG dapat meningkatkan respon imun Th1 (interferon gamma (IFN- $\gamma$ )) dan menekan Th2.

Tujuan. Mengetahui pengaruh vaksinasi BCG terhadap kadar IFN- $\gamma$ serum pasien asma ekstrinsik atopi anak setelah vaksinasi BCG satu kali.

Metode. Penelitian kuasi-eksperimental pretest posttest control group design pada anak asma atopi. Pengacakan perlakuan dilakukan terhadap subjek ke dalam kelompok BCG dan plasebo. Sebelum dan 8 minggu sesudah perlakuan diukur kadar IFN- $\gamma$ serum.

Hasil. Kadar IFN- $\gamma$ serum tidak meningkat sesudah vaksinasi BCG (median 1,580 dan 0,780 pg/ml, $p=$ 0,326 ) dan plasebo (median 1,255 dan $0,670 \mathrm{pg} / \mathrm{ml}, p=0,079$ ). Selisih kadar IFN- $\gamma$ serum kelompok BCG dan plasebo tidak berbeda bermakna (median 0,020 dan $-0,420 \mathrm{pg} / \mathrm{ml}, p=0,449$ ).

Kesimpulan. Kadar IFN- $\gamma$ serum pasien asma ekstrinsik atopi anak tidak meningkat setelah vaksinasi BCG 1 kali. (Sari Pediatri 2008;10(3):207-11).
\end{abstract}

Kata kunci: asma ekstrinsik atopi, interferon gamma, vaksinasi BCG

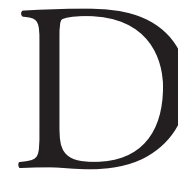

alam duapuluh tahun terakhir terjadi peningkatan prevalensi asma pada anak di seluruh dunia. ${ }^{1,2}$ Salah satu hipotesis yang berkembang untuk menjelaskan hal

\footnotetext{
Alamat Korespondensi:

Dr. Diana Devi Takumansang., SpA(K). Bagian Ilmu Kesehatan Anak Fakultas Kedokteran Universitas Sam Ratulangi, Manado RSU Prof. Dr. R.D Kandou Manado Jl. Raya Tanahwangko, Malalayang, Manado Telp (0431) 821652,/Fax (0431) 859091, E-mail : ikarsup@telkom.net
}

tersebut adalah hygiene hypothesis, membaiknya higiene menyebabkan paparan terhadap mikroba berkurang dan menurunkan kejadian penyakit infeksi, yang mempengaruhi perkembangan sistem imun. ${ }^{3}$

Infeksi mikobakterium tuberkulosis akan merangsang respon imun Th1 dan menekan Th2. ${ }^{4}$ Dari penelitian didapatkan vaksinasi BCG akan meningkatkan ekspresi sel Th1 untuk membentuk IFN- $\gamma$, interleukin-2 (IL-2) dan tumor necrosis factor- $\alpha$ (TNF- $\alpha) .{ }^{5,6}$ Peningkatan sekresi IFN- $\gamma$ akan 
menyebabkan penekanan Th2, menekan sekresi IL-4, IL-5, IL-10 dan penurunan produksi IgE oleh limfosit B. IFN- $\gamma$ yang dihasilkan mampu mengurangi reaksi inflamasi dan hiperreaktifitas bronkus, menekan aktivasi eosinofil dan TGF- $\beta$ sehingga proses fibrosis dan remodeling saluran nafas dihambat. ${ }^{7,8}$ Wongdjaja ${ }^{9}$ mendapatkan adanya peningkatan kadar IFN- $\gamma$ serum secara bermakna pada pasien asma ekstrinsik dewasa satu bulan sesudah vaksinasi BCG tiga kali. Tujuan penelitian untuk mengetahui pengaruh vaksinasi BCG terhadap kadar IFN- $\gamma$ serum pasien asma ekstrinsik atopi anak setelah vaksinasi BCG satu kali.

\section{Metode}

Penelitian bersifat kuasi-eksperimental dengan menggunakan pretest posttest control group design, pada anak sekolah dasar yang menderita asma ekstrinsik atopi di Kecamatan Wenang Kota Manado dari Desember 2006 sampai April 2007. Kriteria inklusi ialah pernah mendapat vaksinasi BCG pada umur $<1$ thn, tidak menggunakan kortikosteroid dalam 3-5 hari terakhir, terdaftar sebagai murid, orangtua setuju dengan menandatangani informed consent. Subjek tidak diikutsertakan apabila sedang demam, mengalami infeksi saluran nafas akut, pernah/sedang sakit tuberkulosis, penyakit kulit yang tidak memungkinkan dilakukan suntikan, gizi buruk, imunokompromais, riwayat/sedang menjalani imunoterapi, riwayat/ sedang menggunakan obat anti-inflamasi, sedang menggunakan obat imunomodulator atau probiotik, tiga bulan terakhir mendapat vaksinasi virus hidup, terjadi reaksi BCG.

Diagnosis asma ditegakkan berdasarkan kuesioner sesuai hasil rapat kerja UKK (Unit Kerja Koordinasi) Respirologi IDAI (Ikatan Dokter Anak Indonesia). Anak dikatakan menderita asma bila memenuhi salah satu atau lebih kriteria berikut, a) Anak pernah menderita asma + pertama kali mengetahui bahwa anak menderita asma yaitu dari dokter atau petugas kesehatan/mantra/bidan/perawat/kader; b) Anak pernah menderita asma + dalam masa 6 bulan terakhir anak sudah pernah menderita asma sebanyak 1 kali atau 2 sampai 5 kali atau hampir setiap bulan; c) Anak pernah mengalami sesak napas + dalam 6 bulan terakhir anak sudah pernah menderita sesak napas sebanyak 1 kali atau 2 sampai 5 kali atau hampir setiap bulan; d) Anak pernah mengalami sesak napas
+ selain sesak napas gejala lainnya yang dilihat adalah waktu bernafas kedengaran bunyi "ngik-ngik"; e) Anak pernah napasnya berbunyi "ngik-ngik" + dalam masa 6 bulan terakhir pernah 1 kali anak mengalami napas berbunyi "ngik-ngik" atau 2 sampai 5 kali atau hampir setiap bulan; f) Anak pernah menderita napas berbunyi "ngik-ngik" + gejala lainnya yang dilihat adalah napas sesak atau batuk-batuk.

Atopi ditegakkan berdasarkan pemeriksaan kadar Ig E total serum, nilai normal sesuai umur 3-9 tahun $<52 \mathrm{IU} / \mathrm{ml}$, dan dewasa $<87 \mathrm{IU} / \mathrm{ml}$. Vaksin BCG yang dipakai diproduksi oleh PT Bio Farma Bandung, disuntikkan 0,1 ml intrakutan pada daerah deltoid lengan atas kanan. Plasebo adalah bahan pelarut BCG disuntikan $0,1 \mathrm{ml}$ di deltoid lengan atas kanan. Interferon $\gamma$ serum diperiksa dengan teknik enzyme - linked immunoadsorbent assay (ELISA). Batas terendah deteksi IFN- $\gamma$ (sensitivities) $0,06 \mathrm{pg} / \mathrm{ml}$.

Pengacakan perlakuan dilakukan terhadap subjek penelitian yang memenuhi kriteria inklusi ke dalam kelompok BCG dan plasebo dan dilakukan pengambilan serum interferon gamma. Selanjutnya diberikan vaksinasi BCG dan plasebo, setelah 8 minggu kemudian dilakukan pengambilan serum interferon gamma kembali. Data penelitian diolah dengan komputer menggunakan SPSS versi 15.0.

\section{Hasil}

Berdasarkan pemeriksaan IgE serum total, didapatkan 38 anak atopi $(97,4 \%)$ sedangkan 1 anak nonatopi (2,6\%). Dari 38 anak asma atopi, 3 anak dikeluarkan dari penelitian karena demam dan 2 anak karena terjadi reaksi BCG. Pada akhir penelitian didapatkan 33 anak, yang terbagi dalam kelompok BCG 17 anak dan 16 anak pada kelompok plasebo.

Tabel 1 memperlihatkan distribusi anak berdasarkan jenis kelamin, terdapat 14 anak laki-laki $(42,4 \%)$ dan 19 anak perempuan (57,6\%). Tabel 2 memperlihatkan distribusi anak berdasarkan kelompok umur, kelompok umur 9-<11 tahun merupakan kelompok umur terbanyak (15 anak, 45,5\%). Pada Tabel 3 memperlihatkan distribusi anak berdasarkan status gizi, secara keseluruhan didapatkan gizi baik merupakan kelompok terbanyak (18 anak, 54,5\%).

Pada Tabel 4 dan 5 memperlihatkan median kadar IFN- $\gamma$ serum sebelum vaksinasi BCG $1,580 \mathrm{pg} / \mathrm{ml}$ 
Tabel 1. Distribusi anak berdasarkan jenis kelamin

\begin{tabular}{|c|c|c|c|c|}
\hline $\begin{array}{l}\text { Jenis } \\
\text { kelamin }\end{array}$ & $\begin{array}{c}\text { Kelompok } \\
\text { BCG }\end{array}$ & $\begin{array}{c}\text { Kelompok } \\
\text { Plasebo }\end{array}$ & & $\begin{array}{l}\text { Total } \\
(\%)\end{array}$ \\
\hline Laki-laki (\%) & $8 \quad(47,1)$ & $6(37,5)$ & 14 & $(42,4)$ \\
\hline Perempuan (\%) & $(52,9)$ & $(62,5)$ & 19 & $(57,6)$ \\
\hline Total (\%) & $17(100,0)$ & $16(100,0)$ & 33 & $(100,0)$ \\
\hline
\end{tabular}

Tabel 2. Distribusi anak berdasarkan kelompok umur

\begin{tabular}{|c|c|c|c|}
\hline $\begin{array}{l}\text { Umur } \\
\text { (tahun) }\end{array}$ & $\begin{array}{c}\text { Kelompok } \\
\text { BCG }\end{array}$ & $\begin{array}{c}\text { Kelompok } \\
\text { Plasebo }\end{array}$ & $\begin{array}{l}\text { Total } \\
(\%)\end{array}$ \\
\hline $5-<7(\%)$ & 0 & $4 \quad(25)$ & $4(12,1)$ \\
\hline $7-<9(\%)$ & $6(35,3)$ & $3 \quad(18,7)$ & $(27,3)$ \\
\hline $9-<11(\%)$ & $8(47,1)$ & $7 \quad(43,8)$ & $15 \quad(45,5)$ \\
\hline $11-<14(\%)$ & $3(17,6)$ & $2 \quad(12,5)$ & $5(15,1)$ \\
\hline Total (\%) & $17(100,0)$ & $16(100,0)$ & $33(100,0)$ \\
\hline
\end{tabular}

Tabel 3. Distribusi anak berdasarkan status gizi.

\begin{tabular}{lrrrrrr}
\hline \multicolumn{1}{c}{$\begin{array}{c}\text { Status } \\
\text { gizi }\end{array}$} & \multicolumn{2}{c}{$\begin{array}{c}\text { Kelompok } \\
\text { BCG }\end{array}$} & \multicolumn{2}{c}{$\begin{array}{c}\text { Kelompok } \\
\text { Plasebo }\end{array}$} & Total \\
\hline Obesitas (\%) & 0 & & 3 & $(18,8)$ & 3 & $(9,1)$ \\
Overweight (\%) & 3 & $(17,6)$ & 0 & & 3 & $(9,1)$ \\
Baik (\%) & 12 & $(70,6)$ & 6 & $(37,5)$ & 18 & $(54,5)$ \\
Kurang (\%) & 2 & $(11,8)$ & 7 & $(43,7)$ & 9 & $(27,3)$ \\
\hline Total (\%) & $17(100,0)$ & 16 & $(100,0)$ & 33 & $(100,0)$ \\
\hline
\end{tabular}

Tabel 4. Hasil uji perbedaan kadar IFN- $\gamma$ serum sebelum dan sesudah vaksinasi BCG dan plasebo

\begin{tabular}{|c|c|c|c|}
\hline \multirow{2}{*}{ Vaksinasi } & \multicolumn{2}{|c|}{ IFN- $\gamma$} & \multirow[b]{2}{*}{$p$} \\
\hline & Median & $\mathrm{Z}$ & \\
\hline \multicolumn{4}{|l|}{ BCG } \\
\hline Sebelum & 1,580 & & \\
\hline Sesudah & 0,780 & $-0,983$ & 0,326 \\
\hline \multicolumn{4}{|l|}{ Plasebo } \\
\hline Sebelum & 1,255 & & \\
\hline Sesudah & 0,670 & $-1,758$ & 0,079 \\
\hline
\end{tabular}

Tabel 5. Hasil pengujian perbedaan selisih kadar IFN- $\gamma$ serum sebelum dan sesudah vaksinasi BCG dan plasebo

\begin{tabular}{llll}
\hline \multirow{2}{*}{ Kelompok } & \multicolumn{2}{c}{ IFN- $\gamma$} & \multirow{2}{c}{$p$} \\
\cline { 2 - 3 } & \multicolumn{1}{c}{ Median } & \multicolumn{2}{c}{ Z } \\
\hline BCG & 0,020 & & \\
Plasebo & $-0,420$ & $-0,757$ & 0,449 \\
\hline
\end{tabular}

$Z$ adalah uji Mann- Whitney dan sesudah vaksinasi $0,780 \mathrm{pg} / \mathrm{ml}$, dan dengan uji Wilcoxon signed rank didapatkan tidak ada perbedaan yang bermakna $(p=0,326)$. Median kadar IFN- $\gamma$ serum sebelum diberi plasebo $1,255 \mathrm{pg} / \mathrm{ml}$ dan sesudah diberi plasebo $0,670 \mathrm{pg} / \mathrm{ml}$, dengan uji Wilcoxon signed rank didapatkan tidak ada perbedaan yang bermakna $(p=0,079)$.

Pada Tabel 5 memperlihatkan median selisih kadar IFN- $\gamma$ serum sebelum dan sesudah vaksinasi BCG $0,020 \mathrm{pg} / \mathrm{ml}$ dan median selisih kadar IFN- $\gamma$ serum sebelum dan sesudah pemberian plasebo $-0,420 \mathrm{pg} /$ $\mathrm{ml}$, dengan uji Mann-Whitney, didapatkan tidak ada perbedaan bermakna antara kelompok BCG dan plasebo $(p=0,449)$

\section{Pembahasan}

Pemeriksaan IgE total serum didapatkan pada 97,4\% anak atopi, asma ekstrinsik pada $90 \%$ asma anak, tampaknya mekanisme serangan melalui reaksi hipersensitivitas tipe 1 dan diperantarai oleh IgE. ${ }^{10,11}$

Dari 33 anak didapatkan laki-laki 14 anak $(42,4 \%)$ dan perempuan 19 anak (57,6\%) dengan perbandingan $1: 1,36$. Angriani $\mathrm{dkk}^{12}$ mendapatkan perbandingan laki-laki dan perempuan sebesar 0,97: 1. Berbeda dengan Laisina ${ }^{13}$ yang mendapatkan perbandingan laki-laki lebih besar dari perempuan yaitu 1,15: 1 . Berdasarkan distribusi umur didapatkan kelompok $9-<11$ tahun merupakan kelompok umur terbanyak pada kedua kelompok. Dilaporkan bahwa asma pada umumnya dimulai sejak masa anak, walaupun perkiraan angka kejadian pada berbagai kelompok umur bervariasi. ${ }^{14}$ Status gizi anak terbanyak adalah status gizi baik $(54,5 \%)$. Laisina ${ }^{13}$ mendapatkan sekitar $33,3 \%$ anak obesitas menderita asma, dan 9,3\% anak yang tidak obesitas menderita asma.

Asma merupakan suatu penyakit yang ditandai adanya inflamasi kronik pada saluran nafas. ${ }^{15}$ Diduga timbulnya inflamasi tersebut disebabkan predominan sel Th2 (IL-4, IL-5) terhadap sel Th1 (IFN- $\gamma$, IL-2). ${ }^{16,17}$ Infeksi mikobakteria dan pemberian vaksin BCG dapat menginduksi respon imun yang diperantarai oleh sel Th1 serta meningkatkan produksi IFN- $\gamma$ dan menekan Th2. ${ }^{18}$ Ozera dkk ${ }^{19}$ di Turki tahun 2002 meneliti pengaruh vaksinasi BCG satu kali pada anak dengan asma atopi, menemukan ekspresi IFN- $\gamma(p<0,01)$ disertai kecenderungan tertekannya ekspresi IL-5 pada delapan minggu setelah vaksinasi. Wongdjaja ${ }^{9}$ mendapatkan 
adanya peningkatan IFN- $\boldsymbol{\gamma}$ serum secara bermakna $(p<0,05)$ pada pasien asma ekstrinsik dewasa satu bulan sesudah vaksinasi BCG tiga kali.

Berbeda dengan hasil penelitian tersebut, Choi $\mathrm{dkk}^{20}$ menemukan penurunan rerata IFN- $\gamma$ pada duabelas minggu setelah vaksinasi baik pada kelompok BCG maupun plasebo, namun terdapat penurunan yang bermakna pada kelompok plasebo; terdapat penurunan yang tidak bermakna IL-4 sesudah vaksinasi BCG sedangkan setelah vaksinasi plasebo meningkat bermakna. Choi $\mathrm{dkk}^{21}$ pada evaluasi satu tahun kemudian melakukan vaksinasi ulang pada kelompok BCG dan vaksinasi pertama pada kelompok plasebo ditemukan penurunan IFN- $\gamma$ pada 4 minggu dan 12 minggu setelah vaksinasi $(p<0,05)$ di kedua kelompok dibandingkan dengan sebelum vaksinasi, penurunan IL-4 bermakna mulai terjadi sejak empat minggu setelah vaksinasi pada kelompok yang mendapat BCG dua kali, sedangkan pada kelompok yang mendapat BCG pertama kali penurunan IL-4 bermakna baru terjadi pada delapan minggu setelah vaksinasi. Dikatakan penurunan IFN- $\gamma$ dan IL-4 di kedua kelompok tersebut diduga karena pengaruh IL$10 .{ }^{16}$ Pengaruh vaksinasi BCG pada makrofag, selain merangsang pembentukan IFN- $\gamma$ juga merangsang IL10. ${ }^{8}$ Interleukin-10 ini berperan dalam mengembalikan keseimbangan respon imun dengan cara menekan sel Th1 dan Th2. ${ }^{22}$

Pada penelitian kami, setelah pemberian vaksin BCG satu kali ataupun plasebo tidak didapatkan peningkatan kadar IFN- $\gamma$ serum dan dari uji statistik tidak ada perbedaan yang bermakna kadar IFN- $\gamma$ serum sebelum dan sesudah diberi BCG berturut-turut $(p=0,326$ dan 0,079). Dari hasil uji perbedaan selisih kadar IFN- $\gamma$ serum antara kelompok BCG dan kelompok plasebo didapatkan tidak ada perbedaan bermakna antara kelompok BCG dan plasebo $(p=0,449)$.

$\operatorname{Vargas}^{23}$ menemukan IFN- $\gamma$ tidak berubah setelah vaksinasi BCG satu kali; dan dikatakan bahwa penanganan asma tidak cukup untuk menghindarkan respon imunologis ke arah Th2 tapi dibutuhkan usaha menghindari alergen yang diduga berhubungan dengan penyakitnya. Kemungkinan tetap terpapar pada alergen tidak dapat disingkirkan dan paparan alergen tersebut akan meningkatkan respon imun Th2 dan menekan respon imun Th1 seperti IFN- $\gamma$. Disimpulkan bahwa kadar IFN- $\gamma$ serum pasien asma ekstrinsik atopi anak tidak meningkat setelah vaksinasi BCG satu kali. Perlu dilakukan penelitian lebih lanjut dengan jumlah sampel yang lebih besar.

\section{Daftar Pustaka}

1. Sumadiono. Hubungan jumlah eosinofil pada darah tepi dengan derajat serangan asma pada anak. Berkala Ilmu Kedokteran 2001;33:159-64.

2. Helms PJ, Christie G.Prospects for preventing asthma. Arch Dis Child 1999;80:401-5.

3. Nafstad P, Magnus P, Jouni JK. Early respiratory infections and childhood asthma. Pediatrics 2000; 106:1-6.

4. Hertzen LV, Klukka T, Mattila H. Asthma, rhinitis, other respiratory diseases. J Allergy Clin Immunol 1999;104:1-10.

5. Von Mutius E, Pearce N, Beasly R.International patterns of tuberculosis and the prevalence of symptoms of asthma, rhinitis, and eczema. Thorax 2000;55:449-53.

6. Hopkin JM. Atopi, asthma, and the mycobcteria.Thorax 2000;55:443-5.

7. Von Hertzen LC, Haahtela T. Could the risk of asthma and atopy be reduced by a vaccine that induced a strong T helper type-1 response? Am J Respir Cell Mol Biol Med 2000;22:139-42.

8. Wild JS, Sur S. CpG oligonucleotide modulation of allergic inflammation. Allergy 2001;56:365-76.

9. Wongdjaja K. Pengaruh vaksinasi BCG terhadap IL 4 dan IFN- $\gamma$ serum pada pasien asma ekstrinsik atopi dewasa. Tesis karya akhir PPDS-1 Bagian Ilmu Penyakit Dalam FK Unsrat, Manado, 2004.

10. Sundaru H. Asma bronchial. Dalam: Soeparman, Soekata H, Waspadji S. Buku ajar ilmu penyakit dalam; Edisi ke 3. Jakarta: Balai Penerbit FK UI; 2001.h. 21-32.

11. Greenberger PA. Asthma. Dalam: Grammer LC, Greenberger PA, Patterson's allergic disease. Edisis ke-6. Philadelphia: Lipincott Williams and Wilkins; 2002. h. 445-506.

12. Angriani H, Farid HM, Dahlan F. Prevalensi asma pada murid sekolah dasar di Kotamadya Ujung Pandang. J Med Nus 1998;19:48-56.

13. Laisina AH. Beberapa faktor risiko yang berhubungan dengan kejadian asma pada anak sekolah dasar di Kecamatan Wenang Kota Manado. Manado: FK UNSRAT, 2005.

14. Kartasasmita CB. Diagnosis dan tatalaksana asma pada anak. Dalam : Firmansayah A, Sastroasmoro S, Trihono PP dkk. Buku naskah lengkap KONIKA XI Jakarta. Jakarta : IDAI; 1999. h. 685-90. 
15. Downs SH, Marks GB, Sporik R. Continued increase in the prevalence of asthma and atopy. Arch Dis Child 2001;84:20-3.

16. Kay AB. Allergy and allergy disease. N Engl J Med 2001;344:30-7.

17. Cohn L, Homer RJ, Niu N. T helper-1 cells and interferon $\gamma$ regulate allergic airway inflammation and mucus production. J Exp Med 1999;190:1309-17.

18. Yilmaz M, Bingol G, Altintas D. Correlation between atopic diseases and tuberculin responses. Alergy 2000;55:664-7.

19. Ozera A, Tukenmezb F, Biricika A. Effect of BCG vaccination on cytokine mRNA expression in atopic children with astma. Immunology Letters 2003;86:29-35.

20. Choi IS, Koh YI. Therapeutic effects of BCG vaccination in adult asthmatic patients: a randomized, controlled trial. Ann Allergy Asthma Immunol 2002;88: 584-91.

21. Choi IS, Koh YI. Effects of revaccination on asthma. Allergy 2003;58:1114-6.

22. Chung KF, Barnes PJ.Cytokines in asthma. Thorax 1999;54:825-57.

23. Vargas MH, Bernal-Alcantara DA, Vaca MA. Effect of BCG vaccination in asthmatic schoolchildren. Pediatr Allergy Immunol 2004;15:415-20. 